\title{
NEW DATA ON CONODONTS, BRACHIOPODS, AND OSTRACODES FROM THE STRATOTYPES OF THE ILMEN AND BUREGI BEDS (FRASNIAN, MAIN DEVONIAN FIELD)
}

\author{
Andrey ZHURAVLEV, Irina EVDOKIMOVA, and Elena SOKIRAN
}

VSEGEI, 74 Sredniy Pr., St Petersburg, 199026, Russia; e-mail: stratigr@mail.wplus.net

Received 20 January 1997, in revised form 18 August 1997

\begin{abstract}
The authors restudied biostratigraphically the stratotypes of the Ilmen Beds and Buregi Beds distinguished by R. Hecker in the Frasnian of the central part of the Main Devonian Field (Lake Ilmen region, Russian Platform). Abundant brachiopod, ostracode, and conodont associations were obtained and one new ostracode species Milanovskya bicristata was described. Both the Ilmen (mainly terrigenous) and Buregi (carbonate) beds correspond to relatively shallow-water facies. Conodont associations permit us to correlate these beds with the Middle-Upper asymmetricus Zone and to recognize two local zones (the Polygnathus pollocki Zone and the P. efimovae Zone). Ostracode, brachiopod, and conodont faunas observed in the Ilmen and Buregi beds resemble the Semilukian ones of the Central Devonian Field. Facial, taphonomical, and some palaeoecological observations allow for the reconstruction of the palaeolandscape succession which was caused by regional sea-level changes.
\end{abstract}

Key words: stratigraphy, Upper Devonian, Frasnian, conodonts, ostracodes, brachiopods.

\section{INTRODUCTION}

The area with the Devonian outcrops in the north part of the Russian Platform, the Main Devonian Field, shows extensive exposures of fossiliferous Frasnian (Upper Devonian) sediments. Geology of the region, including Devonian lithology and stratigraphy, has been investigated since the nineteenth century by numerous researchers, among others by P. Wenjukow, R. Hecker, D. Obruchev, V. Sorokin, and E. Sammet. The Frasnian fossils and biostratigraphy were studied by D. Nalivkin, N. Yakovlev, M. Batalina, E. Glebovskaya, V. Zaspelova, V. Egorov, N. Ovnatanova, L. Kononova, and V. Khalymbadzha.

Many Frasnian outcrops are situated along the Ilmen Glint (Lake Ilmen shore) and the Psizha River and the Perekhoda River banks (Fig. 1). These outcrops show the terrigenous and carbonate sequences divided into several regional 


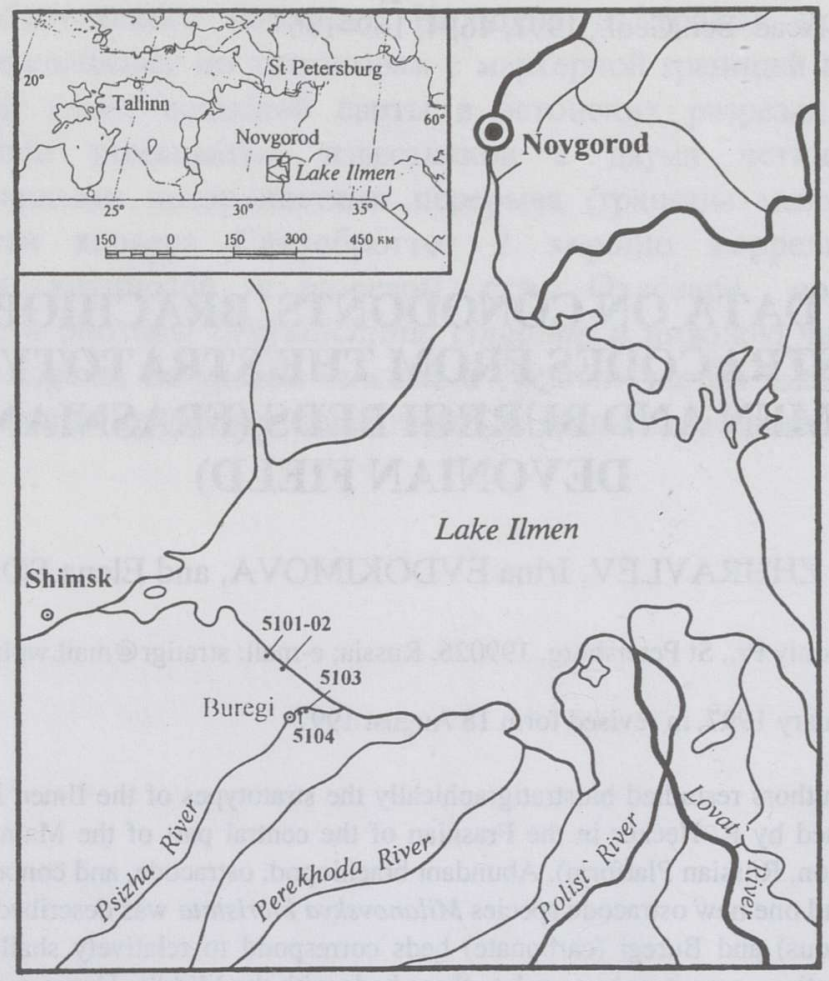

Fig. 1. Location of the sections studied.

stratons - beds. The stratotypes of the Ilmen Beds and the Buregi Beds, which were distinguished by R. Hecker, were restudied by the authors in 1994-95 for conodonts, ostracodes, and brachiopods.

The main aim of our research was to elaborate a biostratigraphic frame for the middle-scale $(1: 200000)$ geological mapping.

The conodont and ostracode specimens figured are deposited in the CNIGR Museum, St Petersburg, Russia, collection No. 13003.

\section{LITHOLOGY AND FACIES The Ilmen Beds}

The Ilmen Beds are represented by claystone, silty claystone (mudstone), siltstone, and sandstone with lenses and layers of bioclastic limestone (pack-, wacke-, float-, and rudstone) (Fig. 2) containing brachiopods, echinoderms, bivalves, gastropods, ostracodes, tentaculites, conodonts, and fishes. Upward the sand and silt content increases, but the content of limestone decreases. The 


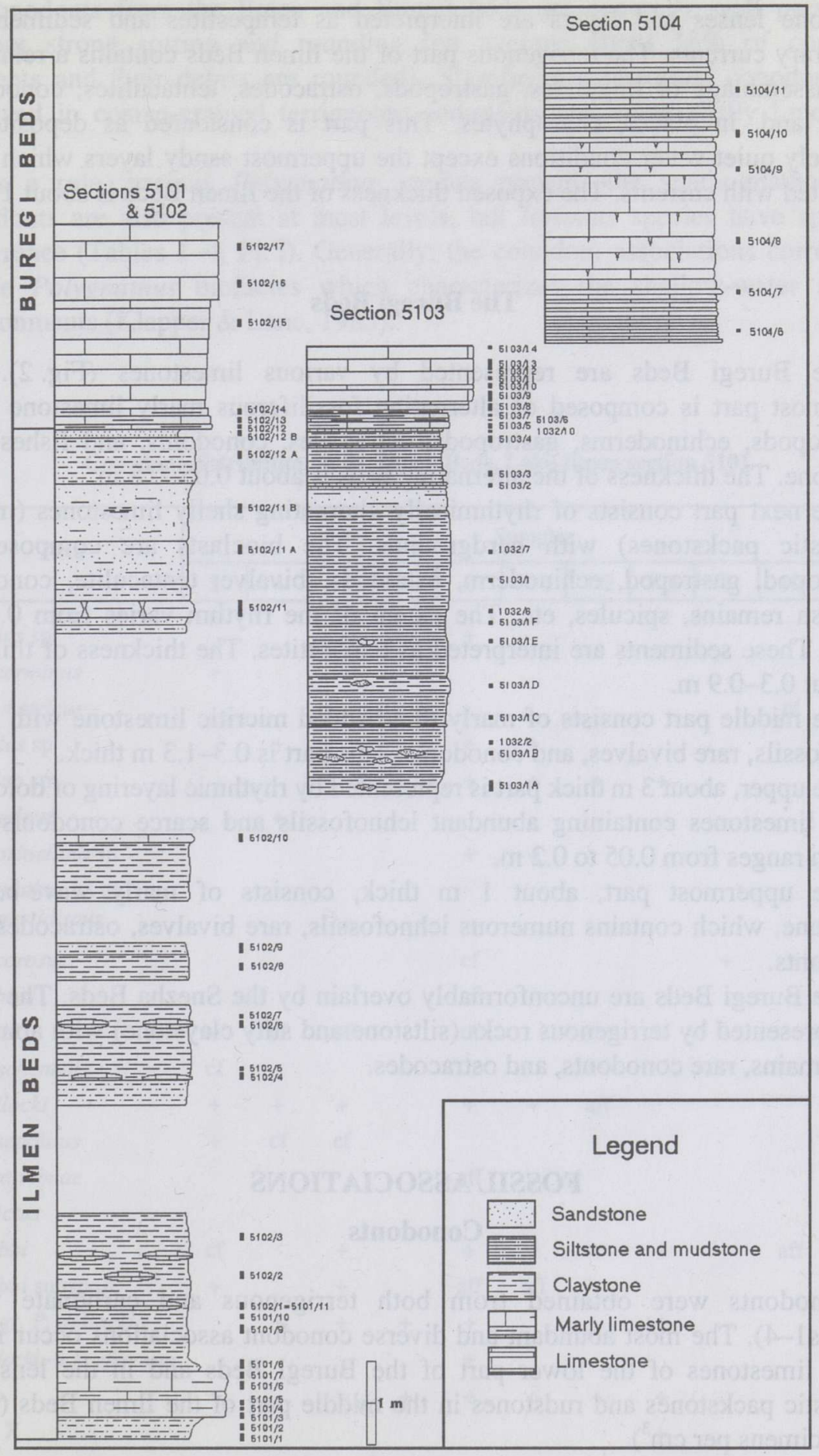

Fig. 2. Lithological columns of the studied sections and the position of the samples. 
limestone lenses and layers are interpreted as tempestites and sediments of temporary currents. The terrigenous part of the Ilmen Beds contains a relatively poor assemblage of lingulates, gastropods, ostracodes, tentaculites, conodonts, fishes, and, in places, charophytes. This part is considered as deposited in relatively quiet-water conditions except the uppermost sandy layers which were deposited with currents. The exposed thickness of the Ilmen Beds is about $12 \mathrm{~m}$.

\section{The Buregi Beds}

The Buregi Beds are represented by various limestones (Fig. 2). The lowermost part is composed of alternating fossiliferous marly limestone (with brachiopods, echinoderms, gastropods, ostracodes, conodonts, and fishes) and claystone. The thickness of the alternating beds is about $0.05-0.8 \mathrm{~m}$.

The next part consists of rhythmically alternating shelly limestones (mainly bioclastic packstones) with hardgrounds. The bioclasts are composed of brachiopod, gastropod, echinoderm, ostracode, bivalve, tentaculite, conodont, and fish remains, spicules, etc. The extent of the rhythm varies from 0.07 to $0.2 \mathrm{~m}$. These sediments are interpreted as tempestites. The thickness of this part is about $0.3-0.9 \mathrm{~m}$.

The middle part consists of marly thin-bedded micritic limestone with many ichnofossils, rare bivalves, and conodonts. This part is $0.3-1.3 \mathrm{~m}$ thick.

The upper, about $3 \mathrm{~m}$ thick part is represented by rhythmic layering of dolomitic marly limestones containing abundant ichnofossils and scarce conodonts. The rhythm ranges from 0.05 to $0.2 \mathrm{~m}$.

The uppermost part, about $1 \mathrm{~m}$ thick, consists of marly wave-bedded limestone, which contains numerous ichnofossils, rare bivalves, ostracodes, and conodonts.

The Buregi Beds are unconformably overlain by the Snezha Beds. The latter are represented by terrigenous rocks (siltstone and silty claystone) with abundant fish remains, rare conodonts, and ostracodes.

\section{FOSSIL ASSOCIATIONS}

\section{Conodonts}

Conodonts were obtained from both terrigenous and carbonate rocks (Tables1-4). The most abundant and diverse conodont associations occur in the shelly limestones of the lower part of the Buregi Beds and in the lenses of bioclastic packstones and rudstones in the middle part of the Ilmen Beds (up to 90 specimens per $\mathrm{cm}^{3}$ ). 
Conodonts from the Ilmen and Buregi beds are generally well preserved, without strong sorting and rounding (on average about $18 \%$ of conodont elements and their debris are rounded). Significantly reworked conodonts are observed in coarse-grained terrigenous sediments and some shelly limestones only.

As a rule, various Polygnathus species prevail; the spathognathodiform conodonts are also present at most levels, but Icriodus species have sporadic occurrence (Tables 1-4, Pl. I). Generally, the conodont associations correspond to the Polygnathus biofacies which characterizes the shallow-water marine environments (Klapper \& Lane, 1985).

Table 1

\section{Conodont distribution in the Ilmen Beds, Lake Ilmen section 5101}

\begin{tabular}{|c|c|c|c|c|c|c|c|c|c|c|c|}
\hline \multirow{2}{*}{ Taxa } & \multicolumn{11}{|c|}{ Samples } \\
\hline & 3 & 4 & $5 \mathrm{C}$ & $5 \mathrm{~L}$ & 6 & $7-1$ & $7-2$ & $7-3$ & 8 & 10 & 11 \\
\hline Icriodus sp. & & & + & + & + & & f & & & 3 & $x^{2}$ \\
\hline I. subterminus & + & & + & & & & & & & 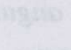 & 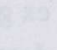 \\
\hline I. symmetricus & & & & & & & F & & & $\mathrm{cf}$ & \\
\hline Oulodus sp. & 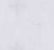 & + & & & + & + & 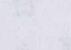 & & & & + \\
\hline Mehlina sp. & & & & & + & + & + & + & & & + \\
\hline M. gradata & ta & + & & & & & & & & & + \\
\hline Pandorinellina sp. & & & & & + & + & 8 & & & & + \\
\hline $\begin{array}{l}\text { Polygnathus ex gr. } \\
\text { P. angustidiscus }\end{array}$ & & & + & & + & & z & & & & + \\
\hline P. decorosus & + & 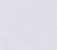 & t. & & $\mathrm{cf}$ & & 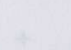 & & + & & + \\
\hline P. dubius & 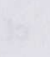 & & $x^{2}=$ & & cf & & & & & we & aff \\
\hline P. lanei & + & $\mathrm{cf}$ & cf & & cf & & 15 & & & & + \\
\hline P. ljaschenkoi & $\mathrm{cf}$ & & & & & & & & & & + \\
\hline P. pollocki & + & + & + & & + & + & aff & & & & aff \\
\hline P. praepolitus & + & cf & cf & & & & ta & & & & + \\
\hline P. seraphimae & 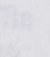 & & & & aff & & & & & & \\
\hline P. strictus & & & & & & & t & & & & $\mathrm{cf}$ \\
\hline P. webbi & $\mathrm{cf}$ & & + & & + & + & + & + & & aff & cf \\
\hline P. webbi subsp. A & + & & + & & aff & aff & & & & & \\
\hline P. ex gr. P. pollocki & & + & + & + & + & & 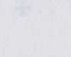 & + & & & + \\
\hline P. pollocki $\rightarrow$ P. efimovae & & & & & + & & & & & & \\
\hline$P$. spp. & & & & + & + & + & + & + & & = & $s^{2}$ \\
\hline$P$. sp. X & & & & & & & & + & & & cf \\
\hline
\end{tabular}




\section{Conodont distribution in the Lake Ilmen section $\mathbf{5 1 0 2}$}

\begin{tabular}{|c|c|c|c|c|c|c|c|c|c|c|c|c|c|c|}
\hline \multirow{3}{*}{ Taxa } & \multicolumn{14}{|c|}{ Samples } \\
\hline & \multicolumn{13}{|c|}{ Ilmen Beds } & \multirow{2}{*}{\begin{tabular}{|c|} 
Buregi \\
Beds
\end{tabular}} \\
\hline & 1 & 2 & 3 & 4-1 & 4-3 & $4-4$ & $4-5$ & 5 & 6 & 7 & 8 & 9 & $12 B$ & \\
\hline Icriodus subterminus & & & & & + & & + & ing if & 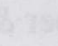 & & & & 7iti & $\mathrm{cf}$ \\
\hline Oulodus sp. & + & + & & & & & & & & & & & & + \\
\hline Mehlina sp. & & & & + & & & + & & & & & & & + \\
\hline M. gradata & & $\mathrm{cf}$ & & & + & & + & & + & + & $\mathrm{cf}$ & & + & \\
\hline M. fitzroyi & & + & & & & + & + & + & $x^{2}$ & & & (1) & & \\
\hline Pandorinellina sp. & & + & & & $?$ & & + & & + & & & & & \\
\hline Polygnathus aequalis & & + & & & & & & & $\mathrm{cf}$ & & & & & \\
\hline$P$. alatus & & cf & & & $\mathrm{cf}$ & & & & + & & & & + & \\
\hline P. angustidiscus & + & + & & & & & aff & & + & & & (aff) & & \\
\hline$P$. posterus & & + & & & & & + & & & & & & & \\
\hline$P$. ex gr. angustidiscus & + & + & & + & + & + & + & & + & & & & & \\
\hline P. decorosus & + & + & & & & & + & (ex gr) & & & aff & & & ex gr,+ \\
\hline P. lanei & + & $\mathrm{cf}$ & aff & & & & + & & + & & & & & + \\
\hline P. ljaschenkoi & aff & + & & & & $\mathrm{cf}$ & + & + & + & Fen & aff & & & \\
\hline P. mosquensis & & & & aff & & & & & & & & & & \\
\hline$P$. penatus & & & & & & + & & & $\mathrm{cf}$ & & & & & \\
\hline P. pollocki & + & + & & + & & & + & & & & & & & \\
\hline P. pseudoxylus & + & + & & 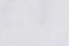 & & & $\sqrt{2}$ & $x^{2}$ & a & & & & & \\
\hline$P$. strictus & & $\sqrt{2}$ & & & & & $\mathrm{cf}$ & & & & & & & \\
\hline P. praepolitus & & + & & & $\mathrm{cf}$ & & + & & + & aff & & & 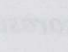 & aff \\
\hline P. seraphimae & ( & & & & & & aff & & cf & & & & & \\
\hline P. webbi & + & $\mathrm{cf}$ & & $\mathrm{cf}$ & + & + & + & cf & + & aff & aff & & & - \\
\hline$P$. webbi subsp. A & + & & & & & 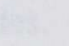 & + & & + & & & & & \\
\hline P. zinaidae & & & & & & $\mathrm{cf}$ & & & $x^{2}$ & & & & & \\
\hline P. dubius & + & aff & & & & aff & & & $\mathrm{cf}$ & & & & & \\
\hline P. uchtensis & & & & & & & & & aff & & & & & \\
\hline$P$. spp. & & + & & + & & & + & + & + & + & & + & & + \\
\hline$P$. ex gr. $P$. pollocki & & $\mathrm{cf}$ & & + & & + & + & & + & & + & & & + \\
\hline P. pollocki $\rightarrow P$. efimovae & + & & & & & & + & & & & & & + & + \\
\hline$P . \mathrm{sp} . \mathrm{X}$ & & + & & + & + & + & & & + & & & & & \\
\hline
\end{tabular}

(), reworked conodonts. 
Conodont distribution in the Lake Ilmen section 5103

\begin{tabular}{c|c|c|c|c|c|c|c|c|c|c|c|c|c|c|c}
\hline & \multicolumn{10}{c}{ Samples } \\
\cline { 2 - 11 } & $\begin{array}{c}\text { Ilmen } \\
\text { Beds }\end{array}$ & \multicolumn{10}{c}{ Buregi Beds } \\
\cline { 2 - 11 } & 1E & 5 & 7 & $8-1$ & $8-2$ & $8-3$ & $8-4$ & $8-5$ & $8-6$ & $8-7$ & 9 & 10 & 12 & 13 & 14 \\
\hline
\end{tabular}

Ancyrognathus

ancyrognathoideus

Icriodus sp.

I. subterminus

Mehlina sp.

M. gradata

M. fitzroyi

Oulodus sp.

Pandorinellina sp.

Polygnathus alatus

$P$. ex gr. angustidiscus

$P$. angustidiscus

aff

(aff)

$P$. decorosus

aff aff $\quad+$

aff

P. dubius

P. efimovae

P. lanei

P. ljaschenkoi

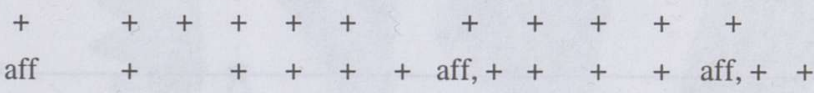

P. pollocki aff

P. praepolitus

P. pseudoxylus

P. seraphimae

cf

P. webbi

$P$. ex gr. $P$. pollocki

$P$. pollocki $\rightarrow P$. efimovae

$P$. spp.

$P$. sp. X

(), reworked conodonts. 


\section{Conodont distribution in the Buregi Beds, Lake Ilmen section 5104}

\begin{tabular}{|c|c|c|c|c|c|}
\hline \multirow{2}{*}{ Taxa } & \multicolumn{5}{|c|}{ Samples } \\
\hline & 1 & 4 & 5 & 9 & 11 \\
\hline \multicolumn{6}{|l|}{ Icriodus subterminus } \\
\hline Mehlina sp. & + & & & 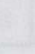 & \\
\hline$M$. gradata & + & + & & + & \\
\hline Oulodus sp. & & + & & & \\
\hline Pandorinellina sp. & + & & & & \\
\hline Polygnathus sp. & & + & & & \\
\hline P. alatus & + & & & & \\
\hline$P$. angustidiscus & $\mathrm{cf}$ & & & & \\
\hline P. efimovae &,$+(+)$ & & & & + \\
\hline P. lanei & cf, aff & & & & \\
\hline P. pollocki & + & & & & \\
\hline P. webbi & $\mathrm{cf}$ & & & & \\
\hline P. pollocki $\rightarrow P$. efimovae & + & & + & & \\
\hline
\end{tabular}

(), reworked conodonts.

\section{PLATE I}

Fig. 1. Polygnathus cf. $P$. seraphimae Ovnatanova et Kononova, 1/13003, x 49, 5103/8-4.

Fig. 2. Polygnathus cf. P. seraphimae Ovnatanova et Kononova, 2/13003, x 74, 5102/6.

Fig. 3. Polygnathus webbi Stauffer, 3/13003, x 43, 5102/4-4.

Fig. 4. Polygnathus aff. P. mosquensis Litvinova, 4/13003, x 62, 5102/4-1.

Fig. 5. Polygnathus pollocki Druce, 5/13003, x 62, 5103/8-5.

Fig. 6. Polygnathus pollocki Druce, 6/13003, x 74, 5102/12.

Fig. 7. Polygnathus praepolitus Kononova, Alekseev, Barskov et Reimers, 7/13003, x 62, 5103/9.

Fig. 8. Polygnathus lanei Kuzmin, 8/13003, x 49, 5103/12.

Fig. 9. Polygnathus ex gr. P. angustidiscus Youngquist, 9/13003, x 25, 5102/2.

Fig. 10. Polygnathus sp. X, 10/13003, x 49, 5102/4-1.

Figs. 11, 13. Polygnathus efimovae Kononova, Alekseev, Barskov et Reimers, 11/13003, 5103/9; $11-\mathrm{x} 43,13-\mathrm{x} 37$.

Fig. 12. Polygnathus ljaschenkoi Kuzmin, 12/13003, x 74, 5102/8.

Fig. 14. Polygnathus aff. P. pennatus Hinde, 13/13003, x 62, 5102/4-4.

Fig. 15. Mehlina gradata Youngquist, 14/13003, x 62, 5102/7.

Fig. 16. Icriodus subterminus Youngquist, 15/13003, x 92.5, 5101/3. 


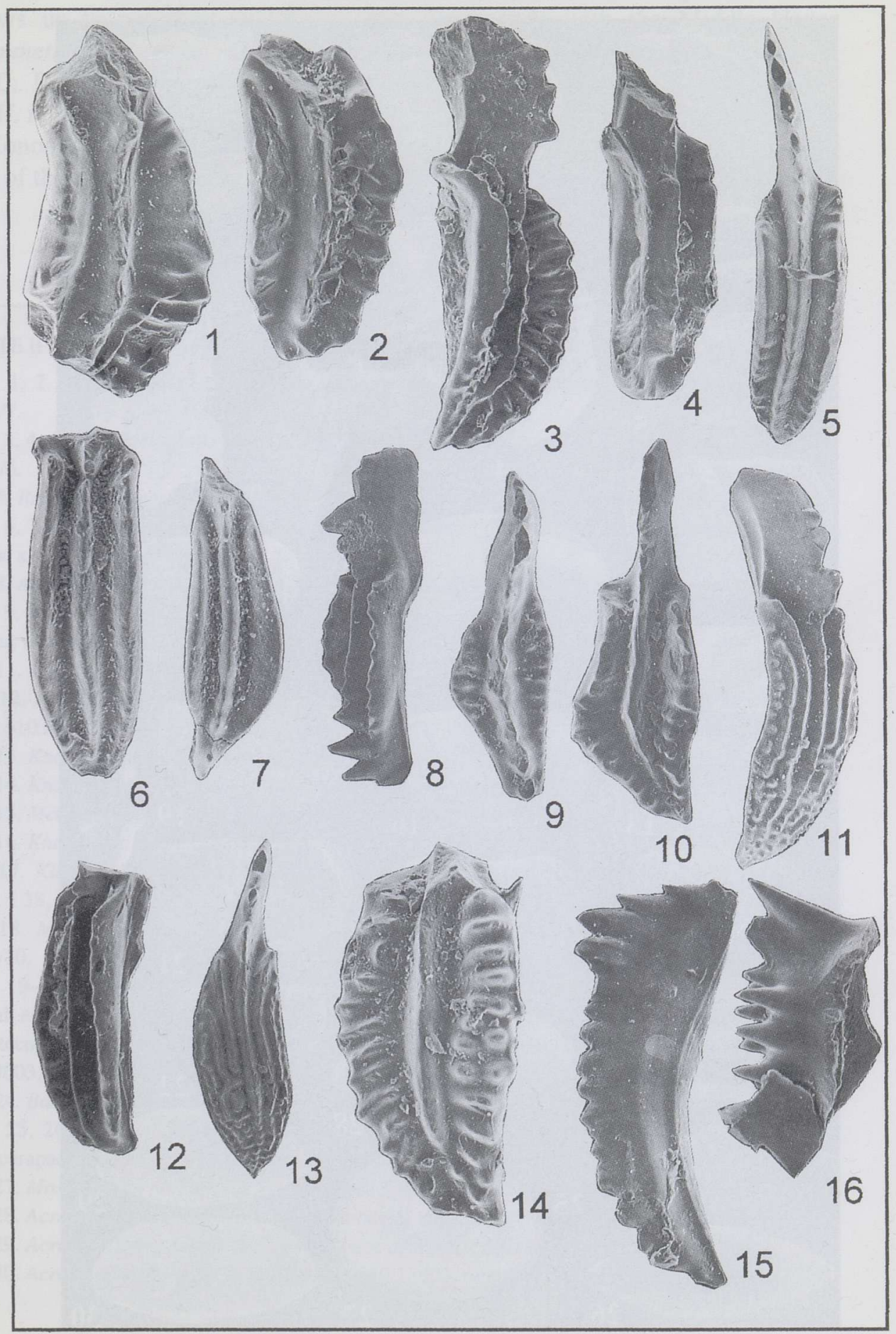




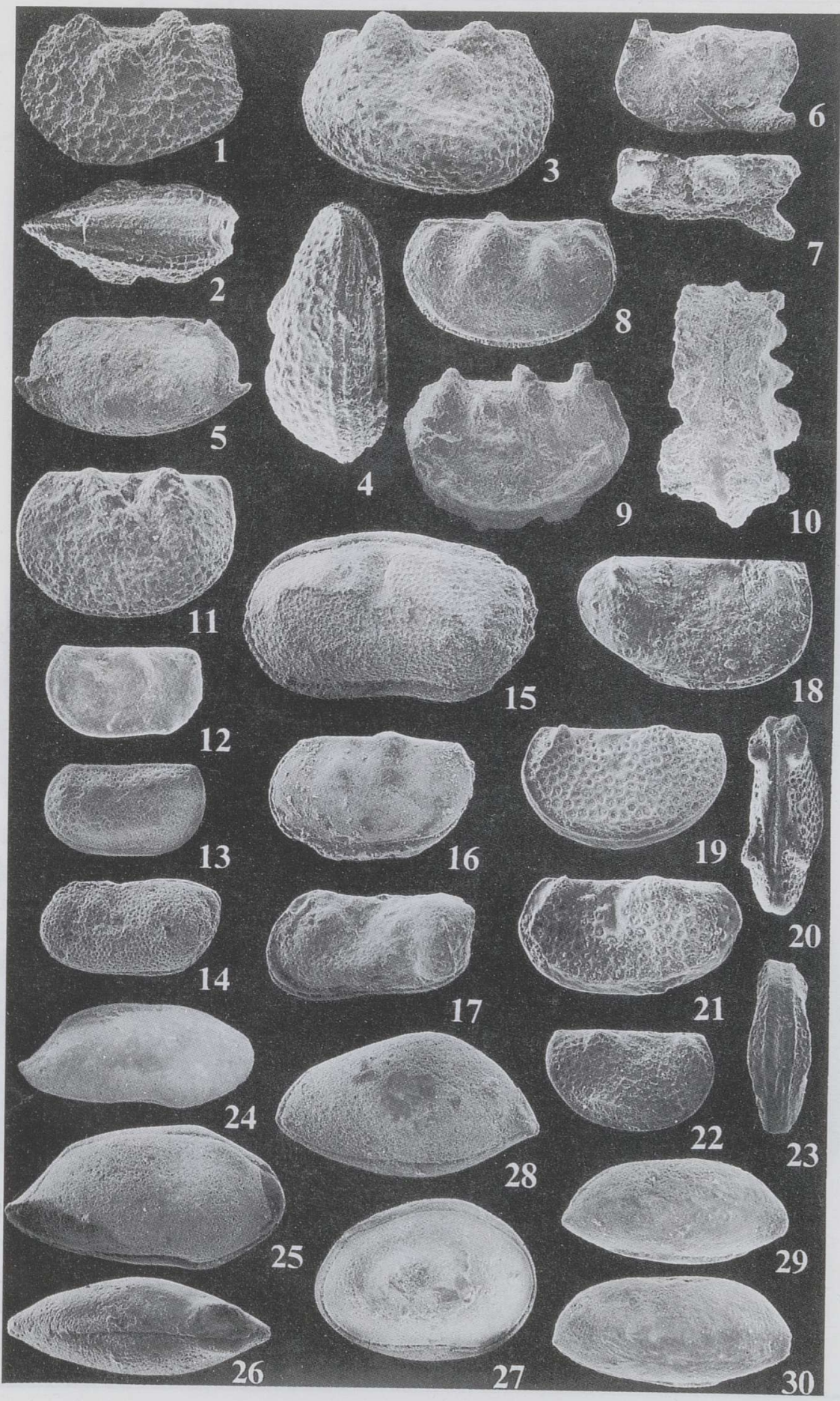


Co-occurrence of Polygnathus pollocki Druce, P. aff. P. pennatus Hinde, $P$. aff. $P$. dubius Hinde, and $P$. angustidiscus Youngquist in the sequence studied allows us to correlate the Buregi and Ilmen beds with the Middle-Upper asymmetricus Zone or punctata-Lower hassi interval (Ziegler \& Sandberg, 1990; Druce, 1976). The occurrence of P. aff. P. mosquensis Litvinova and $P$. aff. $P$. seraphimae Ovnatanova et Kononova suggests, according to Ovnatanova \& Kononova (1996), the correlation of the Ilmen and Buregi beds with the upper part of the Semilukian Regional Stage.

\section{PLATE II}

Figs. 1, 2. Kozlowskiella? sp. 2. Male carapace 16/13003, left lateral and ventral views, x 39, $1032 / 7$.

Figs. 3, 4. Kozlowskiella? sp. 1. Female right valve 17/13003, lateral view, x 34, ventral view, x 36, $1032 / 6$.

Fig. 5. Buregia bispinosa Zasp. Tecnomorphic left valve 18/13003, lateral view, $\mathrm{x} 38$, 1032/6.

Figs. 6, 7. Neodrepanella aff. $N$. tichomirovi Zasp. Female ? left valve 19/13003, lateral and dorsal views, $\mathrm{x} 40,1032 / 2$.

Fig. 8. Acantonodella lutkevichi Zasp. Male ? carapace 20/13003, right lateral view, x 39, 1032/4.

Figs. 9, 10. Acantonodella terciocornuta Zasp. Female ? carapace 21/13003, left lateral view, x 38, ventral view, x 42, 1032/2.

Fig. 11. Kozlowskiella? sp. 1. Male left valve 22/13003, lateral view, x 35, 1032/10.

Fig. 12. Neodrepanella $\mathrm{cf}$. N. parva Zasp. Tecnomorphic carapace 23/13003, left lateral view, x 46, 5103/8-3.

Fig. 13. Knoxiella sp. 1. Tecnomorphic carapace 24/13003, left lateral view, x 37, 5103/8-3.

Fig. 14. Knoxiella sp. 2. Female carapace 25/13003, left lateral view, x 40, 5103/8-3.

Fig. 15. Mennerella sp. Male carapace 26/13003, left lateral view, x 38, 5103/8-3.

Fig. 16. Knoxites sp. Male carapace 27/13003, left lateral view, x 38, 1032/10.

Fig. 17. Kloedenellitina $\mathrm{cf}$. Kl. pseudosygmaeformis Eg. Female carapace 28/13003, left lateral view, $x$ 38, 5103/8-3.

Fig. 18. Milanovskya bicornis Gleb. et Zasp. Female right valve 29/13003, lateral view, x 41, $1032 / 10$.

Figs. 19-23. Milanovskya bicristata sp. nov. 19, 20 - male carapace, holotype 30/13003, left lateral and dorsal views, x 41; 21 - female left valve, allotype 31/13003, lateral view, x 37; 22 - tecnomorphic carapace 32/13003, right lateral view, x 39;23 - tecnomorphic carapace 33/13003, ventral view, x 39, 5103/8-3.

Fig. 24. Bairdia aff. B. raabenae Eg. Carapace 34/13003, right lateral view, x 44, 5103/8-4.

Figs. 25, 26. Bairdia aff. B. uchtaensis Eg. 25 - carapace 35/13003, right lateral view, x 40; 26 - carapace 36/13003, dorsal view, x 40, 5103/8-3.

Fig. 27. Mossolovella philippovae Eg. Carapace 37/13003, right lateral view, x 40, 5103/8-3.

Fig. 28. Acratia sp. Carapace 38/13003, right lateral view, x 38, 5103/8-6.

Fig. 29. Acratia aff. A. gassanovae Eg. Carapace 39/13003, right lateral view, x 44, 5103/8-3.

Fig. 30. Acratia cf. A. buregiana Eg. Carapace 40/13003, right lateral view, x 44, 5103/8-3. 
Aristov (1988, 1994) reported Ancyrodella gigas Youngquist from the Semilukian deposits of the central part of the Russian Platform. This suggests correlation of the Semilukian with the Middle-Upper asymmetricus Zone (Schumacher, 1976; Ziegler \& Sandberg, 1990; Ovnatanova \& Kuz'min, 1991). Thus, the interval studied appears to correlate with the Upper Semilukian and the Middle-Upper asymmetricus Zone (Fig. 3).

The main change in conodonts, marked by the first appearance of Polygnathus efimovae Kononova, Alekseev, Barskov et Reimers sensu stricto, coincides with the Ilmen-Buregi boundary. Kononova and Ovnatanova (1996, oral presentation) proposed the $P$. efimovae Zone as corresponding to the whole Semilukian Regional Stage (see also Kononova et al., 1996). The data obtained by us allow for recognition of two upper Semilukian local conodont zones: the $P$. pollocki Zone in the Ilmen Beds and the P. efimovae Zone in the Buregi Beds. These zones are distinguished in several sections in the Lake Ilmen region. It is possible that the difference in conodont associations of these two zones is rather due to a facies change at the Ilmen-Buregi boundary than to an evolutionary event, and the zones are ecological in nature.

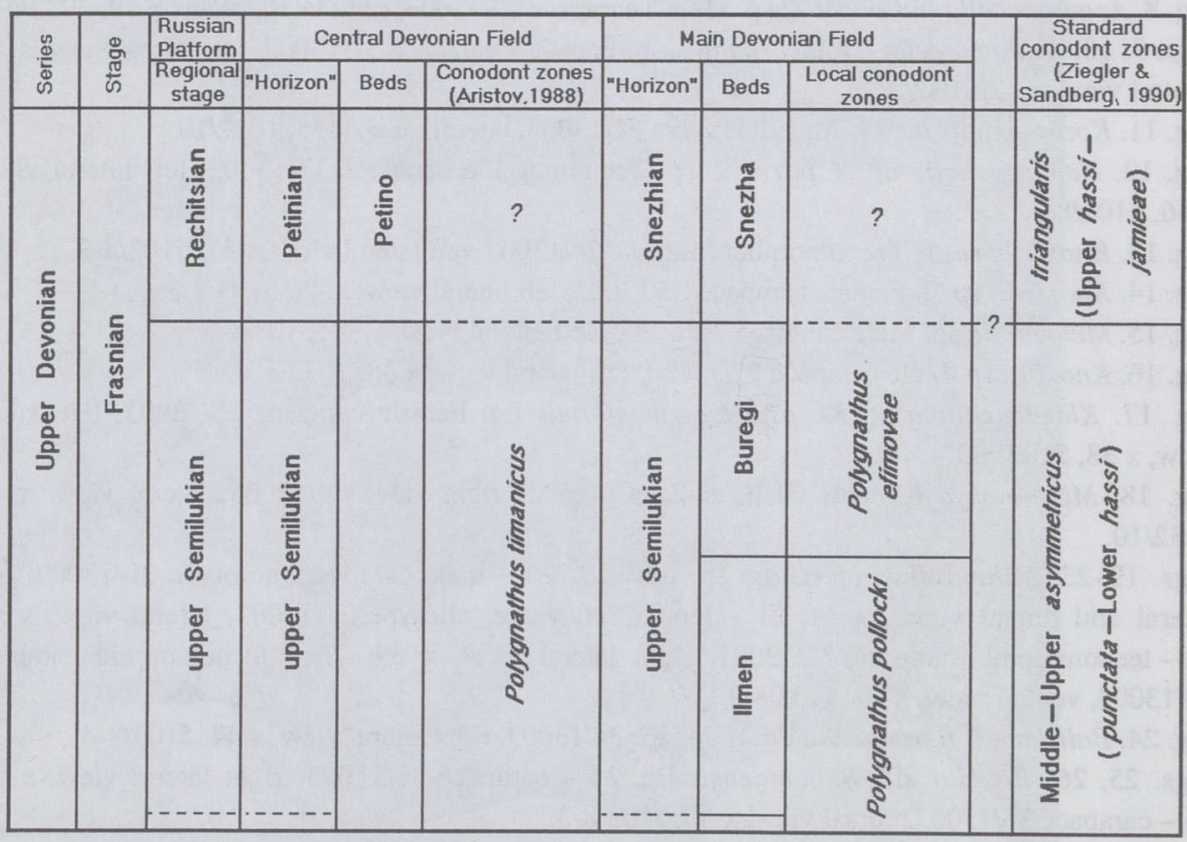

Fig. 3. Stratigraphical chart. 


\section{Ostracodes}

Abundant ostracodes were obtained from the Ilmen Beds and the lower part of the Buregi Beds (Table 5, Pl. II). Ostracodes recovered from the Ilmen Beds are relatively well preserved. The presence of numerous complete carapaces (about $80 \%$ ) and various instars suggests the absence of strong postmortem reworking (Fig. 4). The Buregi Beds are also characterized by well-preserved ostracode carapaces without strong disarticulation (about $65 \%$ of complete carapaces). In both the Ilmen and Buregi beds ostracode shells are sporadically recrystallized or replaced by phosphates and Fe minerals.

Table 5

Ostracode distribution in the Ilmen and Buregi beds

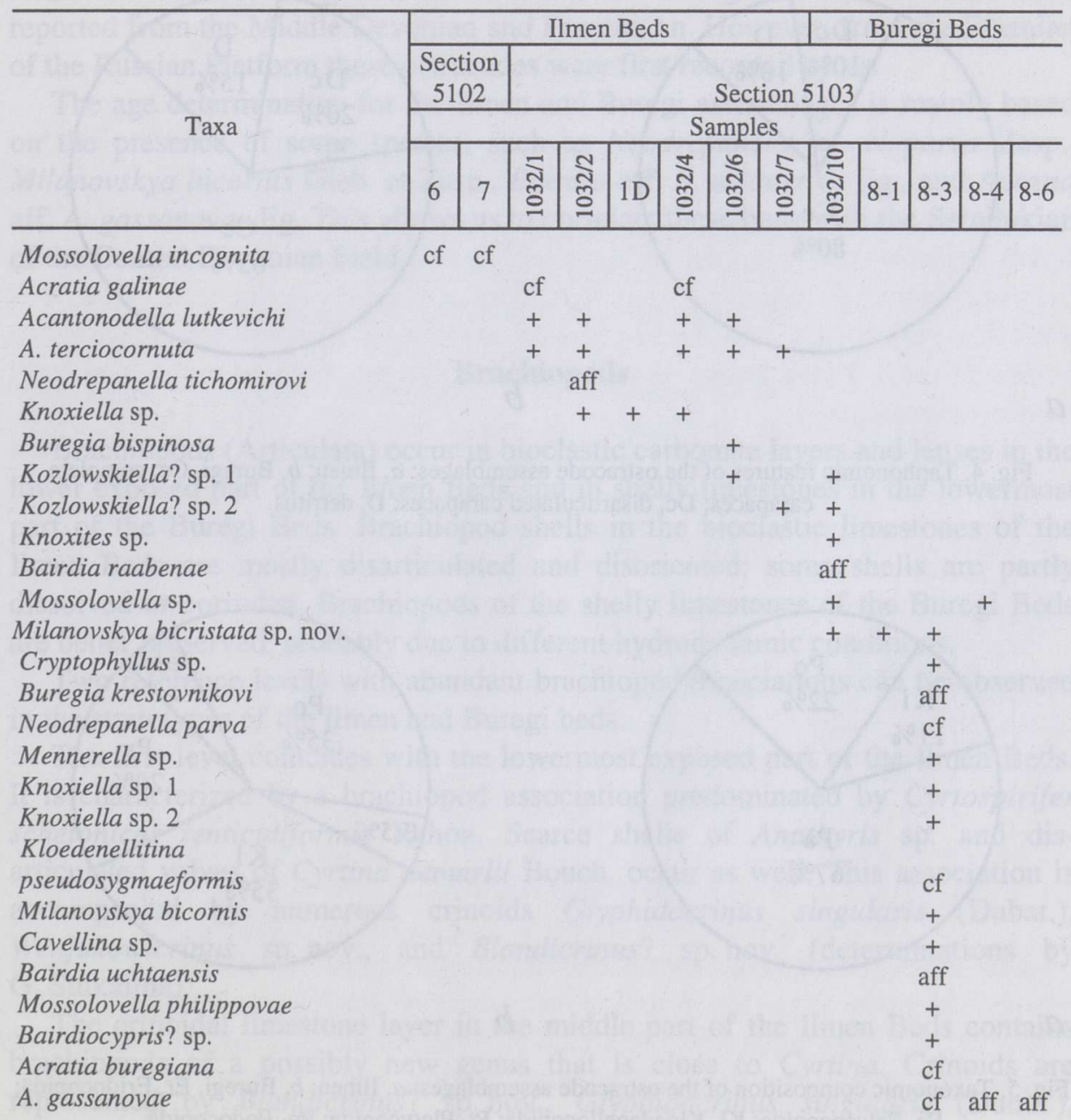


Two ostracode assemblages with different taxonomic compositions were distinguished in the Ilmen and Buregi beds. This taxonomical distinction possibly reflects different environments during Ilmen and Buregi times.

The first assemblage, obtained from the mudstone of the Ilmen Beds, is mainly represented by palaeocopids with ornamented carapaces (Kozlowskiella, Acantonodella, Neodrepanella, and also rare Buregia), comprising about $67 \%$ of the total number of species. This association also contains kloedenellocopids (Knoxiella) and podocopids (Mossolovella and Acratia), accounting to $11 \%$ and $22 \%$, respectively (Fig. 5). The Ilmen assemblage contains some species not reported from the Ilmen Beds by previous investigators. For example, Acantonodella terciocornuta Zasp. and Buregia bispinosa Zasp. were considered as typical of the Snezha Beds only (Zaspelova, 1959).

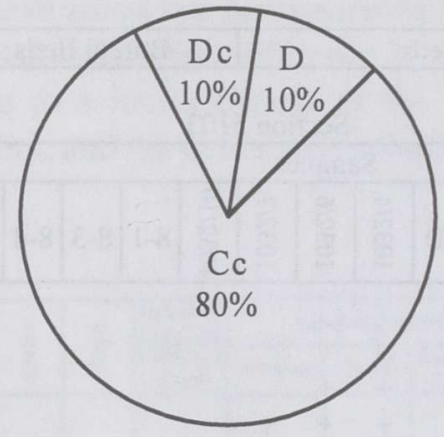

$a$

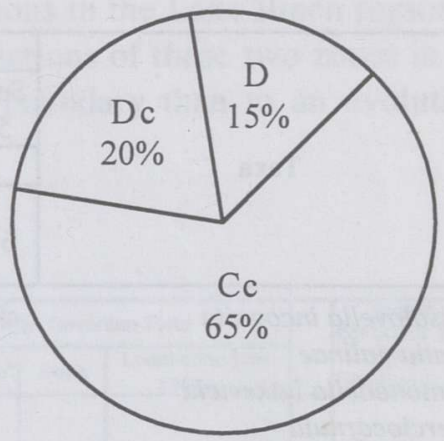

$b$

Fig. 4. Taphonomic features of the ostracode assemblages: $a$, Ilmen; $b$, Buregi. Cc, complete carapaces; Dc, disarticulated carapaces; $\mathrm{D}$, detritus.

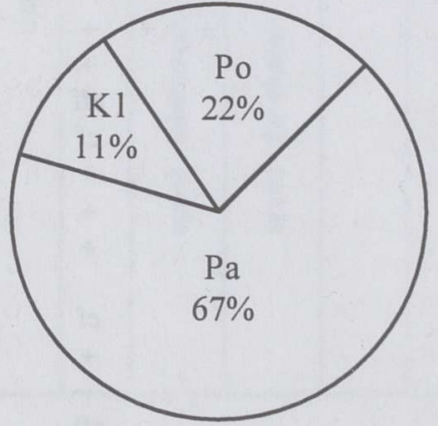

$a$

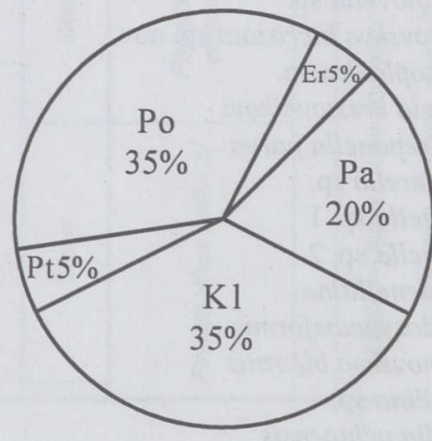

$b$

Fig. 5. Taxonomic composition of the ostracode assemblages: $a$, Ilmen; $b$, Buregi. Er, Eridocopida; $\mathrm{Pa}$, Palaeocopida; Kl, Kloedenellocopida; Pt, Platycopida; Po, Podocopida. 
The second assemblage, derived from the shelly limestones in the lower part of the Buregi Beds, is the most abundant and diverse. It is characterized by numerous sculptured kloedenellocopids (Knoxites, Knoxiella, Mennerella, Kloedenellitina, and Milanovskya) and smooth-shelled podocopids (Bairdia, Mossolovella, Acratia, and Bairdiocypris), each making up 35\%. This association contains also palaeocopids (Buregia, Kozlowskiella, and Neodrepanella), which form about 20\%. Eridocopids (Cryptophyllus) and platycopids (Cavellina) are scarce (about $5 \%$ of the total number of species each) (Fig. 5).

It should be noted that we obtained so rich ostracode association from the Buregi limestones using the acetolysis method. Many species, except Kloedenellitina cf. K. pseudosygmaeformis Eg. and Acratia cf. A. buregiana Eg., had not been found in these deposits before. Ostracodes of the genus Kozlowskiella, occurring both in the Ilmen and Buregi beds, have earlier been reported from the Middle Devonian and Famennian. However, from the Frasnian of the Russian Platform these ostracodes were first recorded by us.

The age determination for the Ilmen and Buregi assemblages is mainly based on the presence of some species, such as Neodrepanella cf. N. parva Zasp., Milanovskya bicornis Gleb. et Zasp., Bairdia aff. B. uchtaensis Eg., and Acratia aff. A. gassanovae Eg. This allows us to correlate these beds with the Semilukian of the Central Devonian Field.

\section{Brachiopods}

Brachiopods (Articulata) occur in bioclastic carbonate layers and lenses in the lower exposed part of the Ilmen Beds and in shelly limestones in the lowermost part of the Buregi Beds. Brachiopod shells in the bioclastic limestones of the Ilmen Beds are mostly disarticulated and disoriented; some shells are partly dissolved or corroded. Brachiopods of the shelly limestones of the Buregi Beds are better preserved, probably due to different hydrodynamic conditions.

Two reference levels with abundant brachiopod associations can be observed in the stratotypes of the Ilmen and Buregi beds.

The first level coincides with the lowermost exposed part of the Ilmen Beds. It is characterized by a brachiopod association predominated by Cyrtospirifer schelonicus tenticuliformis Rzhon. Scarce shells of Anathyris sp. and disarticulated valves of Cyrtina demarlii Bouch. occur as well. This association is accompanied by numerous crinoids Glyphidocrinus singularis (Dubat.), Wenjukowicrinus sp. nov., and Blandicrinus? sp. nov. (determinations by G. Stukalina).

The crinoidal limestone layer in the middle part of the Ilmen Beds contains brachiopods of a possibly new genus that is close to Cyrtina. Crinoids are represented by Blandicrinus? sp. nov., Glyphidocrinus singularis (Dubat.), 
G. infimus (Dubat.), Wenjukowicrinus sp. nov., and Hexacrinites argutus Yelt. (determinations by G. Stukalina).

The second level coincides with the lowermost part of the Buregi Beds. It is characterized by a more diverse brachiopod association. This association is dominated by Pseudoatrypa uralica (Nal.), Tenticospirifer tenticulum (Vern.), and accompanied by Anathyris helmersenii (Bouch.) and Chonetipustula petini (Nal.). Scarce valves of Cyrtospirifer sp. occur as well. According to Nalivkin (1941) and Hecker (1983), Ps. uralica appears first and has the acme in the Buregi Beds, possibly due to the Buregian transgression. The second brachiopod level is reliably traced laterally and has a relatively uniform taxonomic composition.

The brachiopods reported permit us to correlate the Buregi and Ilmen beds with the Semilukian of the central part of the Russian Platform.

\section{PALAEOECOLOGY}

Satisfactory preservation of the fossil communities of both the benthic (ostracodes and brachiopods) and nekto-benthic and nekto-planktic (conodonts) fauna allows us to reconstruct some parameters of the palaeoecosystem. The Ilmen Beds are characterized by the dominance of Polygnathus species among the conodonts, the presence of palaeocopid and kloedenellocopid ostracodes with few podocopids, and the brachiopod association Cyrtospirifer schelonicus tenticuliformis. These faunal associations suggest the shallow-water nearshore marine environments.

Echinoderms, conodonts of the Polygnathus biofacies, the Pseudoatrypa uralica-Tenticospirifer tenticulum brachiopod association, and palaeocopideridocopid-kloedenellocopid ostracode biofacies with abundant bairdiaceans occur in the lower part of the Buregi Beds. This suggests the shallow-water offshore marine environments with normal salinity and near-bottom aeration.

The absence of abundant benthic fauna in the middle and upper parts of the Buregi Beds indicates abnormal near-bottom salinity and aeration. The presence of conodonts in these sediments allows us to suggest good aeration and normal salinity for the upper part of the water column. Probably the halocline occurred there.

\section{CONCLUSIONS}

The present work is the first comprehensive study of conodonts, ostracodes, and brachiopods from the Frasnian sequence of the Main Devonian Field. However, the data presented are tentative. The stratotypes of the Ilmen and Buregi beds show abundant and diverse shallow-water faunas of conodonts, 
ostracodes, and brachiopods. The fossils are mostly well preserved and allow not only for biostratigraphic interpretations but also for palaeoecosystem analysis. The latter is one of the items for future investigations.

In general, the age determination on brachiopods and ostracodes agrees with that on conodonts. Thus, in the type sections the Ilmen and Buregi beds correspond to the upper Semilukian or to the upper part of the asymmetricus Zone (Fig. 3).

The drilling data suggest that the lowermost part of the Ilmen Beds (as a lithological unit) is not exposed in the type section. That is why it is necessary to find a new stratotype with the complete Ilmenian succession and to study its faunal associations. It is also planned to investigate in detail the Buregi-Snezha boundary beds and to trace the lateral changes in the faunal associations in both the Ilmen and Buregi beds.

\section{SYSTEMATIC PALAEONTOLOGY}

Order KLOEDENELLOCOPIDA Scott, 1961 Superfamily BEYRICHIOPSACEA Henningsmoen, 1953

Family MILANOVSKYIDAE Abushik, 1990

Genus Milanovskya Egorov, 1950

Milanovskya bicristata Evdokimova, sp. nov.

Pl. II, figs. 19-23

Name. Latin crista, crest; referring to shape of lobes L1 and L3.

Holotype. 30/13003 CNIGR Museum, St Petersburg; male carapace; Pl. II, figs. 19, 20. Frasnian, lower part of the Buregi Beds; Main Devonian Field, Novgorod region, the right bank of the Psizha River, near the village of Buregi.

Material. Over 50 well-preserved female and tecnomorphic carapaces and valves from the type locality.

Diagnosis. Species of Milanovskya with distinct S2; L1 and L3 crested, both extending slightly higher above hinge line; ventral ridge thin and rather short.

Description. Carapace subelliptical in lateral view, dorsally truncated, flattened laterally; adductorial sulcus distinct, sometimes pit-like; L1 narrow, crested; L3 forms a broad crest turned backward; both L1 and L3 extend slightly higher above hinge line; marginal ridge narrow, roller-like; ventral ridge thin, comparatively short, keel-like, situated near marginal ridge; surface reticulate. Females longer and lower than males, rounded-rectangular in outline; ventral ridge long, filament-like; posterior part of valves with distinct swelling.

Changeability. Young specimens have all features of males, but they are smaller and have shorter ventral ridge.

Measurements, mm (Fig. 6). Holotype: L-0.69, H-0.42. 


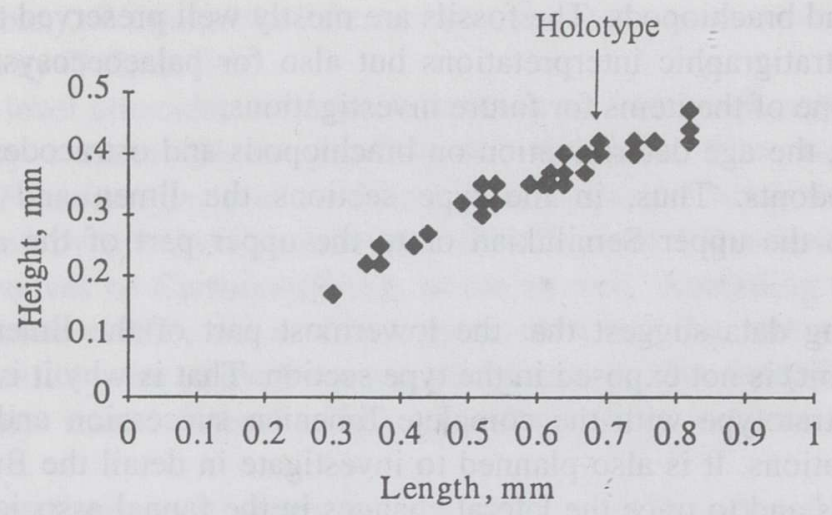

Fig. 6. Size variation of Milanovskya bicristata sp. nov.

Comparison. M. bicristata is similar to M. bicornis Gleb. et Zasp. and $M$. ventricristata Zasp., but it is distinguished by the presence of two crests but not spines at the dorsal margin. In addition, the absence of selvage along the ventral margin and posterior end, and also the presence of ventral ridge differentiate $M$. bicristata from $M$. ventricristata.

Distribution. Frasnian, lower part of the Buregi Beds; Main Devonian Field.

\section{ACKNOWLEDGEMENTS}

This work was partly financed by the Ilmen Geological Mapping Project. The authors are grateful to V. Verbitskii and Yu. Nenashev (VSEGEI) for assistance with field work, G. Stukalina (VSEGEI) for data on crinoids. M. Rzhonsnitskaya (VSEGEI), A. Abushik (VSEGEI), and A. Kuz'min (VNIGNI) are thanked for comments, and P. Stepanov for photographs.

This paper is a contribution to IGCP Project 406 Circum-Arctic Palaeozoic Vertebrates.

\section{REFERENCES}

Aristov, V. A. 1988. Devonian Conodonts of Central Devonian Field (Russian Platform). Nauka, Moscow (in Russian).

Aristov, V. A. 1994. Devonian and Lower Carboniferous Conodonts of the Eurasia. Nauka, Moscow (in Russian). 
Druce, E. C. 1976. Conodont biostratigraphy of the Upper Devonian Reef Complexes of the Canning Basin, Western Australia. Bull. Austral. Bur. Miner. Resour., Geol. Geophys., 158, 1-234.

Hecker, R. F. 1983. Tafonomicheskie $i$ ekologicheskie osobennosti fauny $i$ flory Glavnogo Devonskogo Polya. Nauka, Moscow (in Russian).

Klapper, G. \& Lane, H. R. 1985. Upper Devonian (Frasnian) conodonts of the Polygnathus biofacies, N.W.T., Canada. J. Palaeontol., 59, 4, 904-951.

Kononova, L. I., Alekseev, A. S., Barskov, I. S. \& Reimers, A. N. 1996. New species of Polygnathid conodonts from Frasnian of Moscow Syneclise. Paleontol. Zh., 3, 94-99 (in Russian).

Nalivkin, D. V. 1941. Brakhiopody Glavnogo Devonskogo Polya. In Fauna Glavnogo Devonskogo Polya (Batalina, M. A., Bulvanker, E. Z., Hecker, R. F. et al., eds.). USSR AS Press, Moscow-Leningrad, 139-226 (in Russian).

Ovnatanova, N. S. \& Kononova, L. I. 1996. Some new Frasnian species of Polygnathus genus (Conodonta) from the Central part of the Russian Platform. Paleontol. Zh., 1, 54-60 (in Russian).

Ovnatanova, N. S. \& Kuz'min, A. V. 1991. Konodonty tipovykh razrezov domanikovoj svity na Yuzhnom Timane. Izv. AN SSSR, Ser. Geol., 3, 37-50 (in Russian).

Schumacher, D. 1976. Conodont biofacies and palaeoenvironments in Middle Devonian-Upper Devonian boundary beds, central Missouri. In Conodont Paleoecology. Geol. Assoc. Canada Special Paper, 15, 159-169.

Zaspelova, V. S. 1959. Ostrakody i ikh znachenie dlja stratigrafii devona severo-zapadnykh oblastej Russkoj platformy. Mikrofauna SSSR, 10, 5-131 (in Russian).

Ziegler, W. \& Sandberg, C. A. 1990. The Late Devonian standard conodont zonation. Courier Forsch.-Inst. Senckenberg, 121, 1-115.

\section{UUSI ANDMEID KONODONTIDE, BRAHHIOPOODIDE JA OSTRAKOODIDE ESINEMISE KOHTA ILMENI JA BUREGI KIHTIDE STRATOTÜÜPIDES (FRASNE, PEADEVONIVÄLI)}

\section{Andrei ŽURAVLJOV, Irina JEVDOKIMOVA ja Jelena SOKIRAN}

Biostratigraafiliselt on uuritud Ilmeni ja Buregi kihtide (Frasne) stratotüüpe, mille eraldas Peadevoniväljal (Ilmeni järve ümbruses) välja R. Hecker 1932. aastal. On kindlaks tehtud rikkalikud brahhiopoodide, ostrakoodide ja konodontide assotsiatsioonid ning kirjeldatud uut ostrakoodiliiki Milanovskya bicristata. Nii karbonaatsed Buregi kui ka valdavalt terrigeensed Ilmeni kihid on tekkinud suhteliselt madalaveelistes tingimustes. Konodontide alusel korreleeritakse neid kihte asymmetricus'e tsooni kesk- ja ülemosaga. On püstitatud kaks kohalikku konodonditsooni (Polygnathus pollocki ja P. efimovae). Nimetatud assotsiatsioonide poolest on Ilmeni ja Buregi kihid sarnased Semiluki lademe omadega Tsentraaldevoniväljal. Fatsiaalsete, tafonoomiliste ja paleoökoloogiliste vaatluste alusel on rekonstrueeritud uuritava ala maastikuline suktsessioon, mille peapõhjuseks olid meretaseme regionaalsed muutused. 


\section{НОВЫЕ ДАННЫЕ О КОНОДОНТАХ, БРАХИОПОДАХ И ОСТРАКОДАХ ИЗ СТРАТОТИПОВ ИЛЬМЕНСКИХ И БУРЕГСКИХ СЛОЕВ (ФРАН, ГЛАВНОЕ ДЕВОНСКОЕ ПОЛЕ)}

Андрей ЖУРАВЛЕВ, Ирина ЕВДОКИМОВА и Елена СОКИРАН

Биостратиграфически изучены стратотипы ильменских и бурегских слоев, выделенных Р. Ф. Геккером во фране Главного девонского поля (Русская платформа, район оз. Ильмень). Выявлены обильные комплексы брахиопод, остракод и конодонтов и описан один новый вид остракод Milanovskya bicristata. Как бурегские (карбонатные), так и ильменские (преимущественно терригенные) отложения соответствуют относительно мелководным фациям. Комплексы конодонтов позволяют скоррелировать эти отложения с зонами средняя-верхняя asymmetricus и установить две местные зоны (Polygnathus pollocki и P. efimovae). Остракодовые, брахиоподовые и конодонтовые комплексы из ильменских и бурегских слоев сходны с таковыми из семилукских отложений Центрального девонского поля. Фациальные, тафономические и некоторые палеоэкологические наблюдения позволили реконструировать палеоландшафтную сукцессию, обусловленную региональными изменениями уровня моря. 